DOI: $10.17516 / 1997-1370-0858$

УДК $33.63,339.332$

\title{
Cereals Export Factors and Impact on Wheat Price in Russian Regions
}

\author{
Evgeny A. Kapoguzov*a, Roman I. Chupin ${ }^{\text {, }}$ \\ Vitaly V.Aleshchenkoc and Alexandr A. Bykov ${ }^{\mathrm{d}}$ \\ ${ }^{a}$ Dostoevsky Omsk State University \\ Omsk, Russian Federation \\ ${ }^{b}$ Omsk Scientific Centre, Siberian Branch \\ of the Russian Academy of Sciences \\ Omsk, Russian Federation \\ 'Institute of Economics and Industrial Engineering \\ Siberian Branch of the Russian Academy of Sciences \\ Novosibirsk, Russian Federation \\ ${ }^{d}$ Siberian Federal Scientific Centre of Agrobiotechnology \\ Russian Academy of Sciences \\ Novosibirsk, Russian Federation
}

Received 06.06.2021, received in revised form 15.10.2021, accepted 10.11.2021

\begin{abstract}
The study describes the problems of wheat exports from Russian regions. The Russian Federation is one of the largest exporters of grain. Taking into account the development of biotechnology in the world, this type of resource claims to be a «new oil.» In the light of this, the Government of the Russian Federation set the task of doubling the export of agricultural products and raw materials until 2024. At the same time, the most promising areas of export are determined - India and China. Speaking of the latter, wheat exports to China began in 2014 and by the end of 2020 accounts for less than $1 \%$ of the total Russian wheat exports. It is assumed that export growth in the Asian direction should be due to the regions of Siberia (Krasnoyarsk Territory, Novosibirsk Region, Omsk Region and Altai Territory), which have never been the main exporters of wheat. In this regard, it becomes necessary to update the scientific provisions of the logistics doctrine based on the results of empirical studies of wheat export factors from Russian regions. The debate on this issue rests on different approaches to determining the significance of export factors. The article provides an overview of key modern approaches, including theories of export and production potential. Based on the integrated approach, as well as machine training methods, the study proposes an analysis of the array of monthly data by 72 regions from 2007 to 2021 years, which includes a set of parameters of export and production potential. As a result, a linear classifier model is proposed, which allows guessing the export status of the region with an accuracy of $96 \%$ based on a set of factors.
\end{abstract}

(c) Siberian Federal University. All rights reserved

* Corresponding author E-mail address: egenk@mail.ru

ORCID: 0000-0001-8083-5654 (Kapoguzov); 0000-0002-8904-1380 (Chupin); 0000-0003-4158-6127 (Aleshchenko); 00000002-5034-6777 (Bykov) 
It is determined that market factors increase the probability of export, while factors of production potential (with the exception of flour production) reduce this probability. This conclusion supports the idea of an integral approach, according to which with the development of primary and deep grain processing in the regions, exports are expected to decrease, while the development of the «free» grain market and an increase in wheat reserves on elevators leads to an increase in Russian grain exports. Thus, taking into account these circumstances, proposals have been formed to increase wheat exports from Siberian regions, which make it possible to offset the negative impact of exports not on the price situation within the regions and to comply with the interests of domestic processors and grain traders.

Keywords: cereals export, grain balances, wheat price, domestic grain shipments, grain reserves, potential production.

The study was carried out according to state grant from the President of the Russian Federation (MK-5244.2021.2).

Research area: economics.

Citation: Kapoguzov, E.A., Chupin, R.I., Aleshchenko, V.V. and Bykov, A.A. (2021). cereals export factors and impact on wheat price in Russian regions. J. Sib. Fed. Univ. Humanit. soc. sci., 14(12), 1782-1794. DOI: 10.17516/1997-1370-0858

\title{
Факторы экспорта зерновых и их влияние на цену пшеницы в российских регионах
}

\author{
Е.А. Капогузов ${ }^{a}$, Р.И. Чупин ${ }^{6}$, \\ В.В. Алещенков и А.А. Быковг \\ ${ }^{a}$ Омский государственный университет им. Ф. М. Достоевского \\ Российская Федераџия, Омск \\ ${ }^{\sigma} О$ мский научный центр Сибирского отделения \\ Российской академии наук \\ Российская Федерация, Омск \\ ${ }^{8}$ Институт экономики и организачии промышленного производства \\ Сибирского отделения Российской академии наук \\ Российская Федерачия, Новосибирск \\ ${ }^{2}$ Сибирский федеральный научный центр агробиотехнологий \\ Российской академии наук \\ Российская Федерация, Новосибирск
}

Аннотация. Исследование посвящено проблеме экспорта пшеницы из российских
регионов. Российская Федерация является одним из крупнейших экспортеров
зерна, и данный вид ресурса (с учетом развития биотехнологий в мире) претендует
на статус «новой нефти». В свете этого Правительством РФ поставлена задача
увеличения экспорта сельскохозяйственной продукции и сырья до 2024 года
вдвое. При этом определены самые перспективные направления экспорта - 
Индия и Китай. Экспорт пшеницы в Китай начался в 2014 году и по итогам 2020 года составляет менее 1 \% от суммарного российского экспорта пшеницы. Предполагается, что рост экспорта в азиатском направлении должен происходить за счет регионов Сибири (Красноярский край, Новосибирская область, Омская область и Алтайский край), которые никогда не являлись основными экспортерами пшеницы. В этой связи необходима актуализация научных положений логистической доктрины на основе результатов эмпирических исследований факторов экспорта пшеницы из российских регионов. Дискуссионность данного вопроса упирается в различные подходы к определению значимости факторов экспорта. В статье предложен обзор ключевых современных подходов, в числе которых теории экспортного и производственного потенциала. Основываясь на интегральном подходе, а также методах машинного обучения, исследователи предлагают анализ массива месячных данных по 72 регионам с 2007 по 2021 год, включающий в себя совокупность параметров экспортного и производственного потенциала. Создана модель линейного классификатора, позволяющая с точностью до 96 \% угадать экспортный статус региона. При этом определено, что рыночные факторы увеличивают вероятность экспорта, тогда как факторы производственного потенциала (за исключением производства муки) сокращают данную вероятность. Этот вывод подтверждает идею интегрального подхода, согласно которой с развитием первичной и глубокой переработки зерна в регионах ожидается сокращение экспорта, тогда как развитие «свободного» рынка зерна и увеличение запасов пшеницы на элеваторах приводят к увеличению экспорта российского зерна. С учетом данных обстоятельств сформированы предложения по увеличению экспорта пшеницы из сибирских регионов, позволяющие нивелировать негативное влияние экспорта на ценовую конъюнктуру внутри регионов и соблюсти интересы внутренних переработчиков и зернотрейдеров.

Ключевые слова: экспорт зерновых, зерновые балансы, цена пшеницы, внутренние поставки зерна, запасы зерна, производственный потенциал.

Работа выполнена за счет средств Гранта Президента РФ (МК-5244.2021.2).

Научная специальность: 08.00.00 - экономические науки.

\section{Introduction}

The Russian's agro-industrial complex has essential resource and export potential. Russian companies supplied over $\$ 13$ billion worth of agricultural products to foreign markets in the first half of 2020 . This is $18 \%$ more compared to the same period last year. Note that the European Union isolated from Russian consumers that year reached a record export rate of the agricultural sector of 137 billion Euro ${ }^{1}$. Consequently, the Russian export potential for agro-industrial products has not yet been fully disclosed.

\footnotetext{
15 years of 'sanctioning'. How the ban on European products affected Russia. Available at: https://quote.rbc.ru/news/ article/5ac37b779a79471cdd2efe4d (Access: 16.03.2021).
}

Experts agree that one of the key drivers of Russian export expansion is grain crops (Rau, 2017). Dynamics of Russian wheat export is shown in Figure 1.

With an increase in the volume of wheat exports in real terms of 1.6 times, the increase in export marginality amounted to only $30 \%$. Despite this, the Russian government indicated that by 2024 the volume of Russian agricultural exports should double - up to $\$ 45$ billion, of which the vast majority of supplies (55\%) will fall on China and India. Achieving this goal will serve as a powerful impetus for the development of agricultural production in the conditions of export expansion of Russian grain. However, it should be understood that the in- 


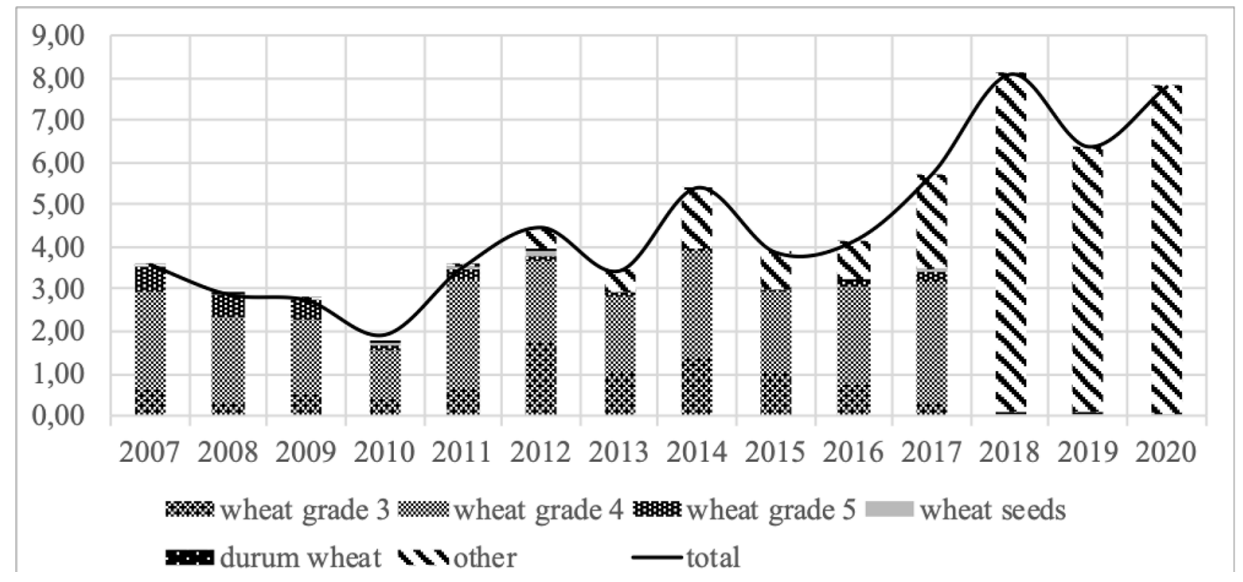

Fig. 1. Dynamics of wheat exports from Russia in 2007-2020, \$ billion

Source: Federal Customs Service of Russia

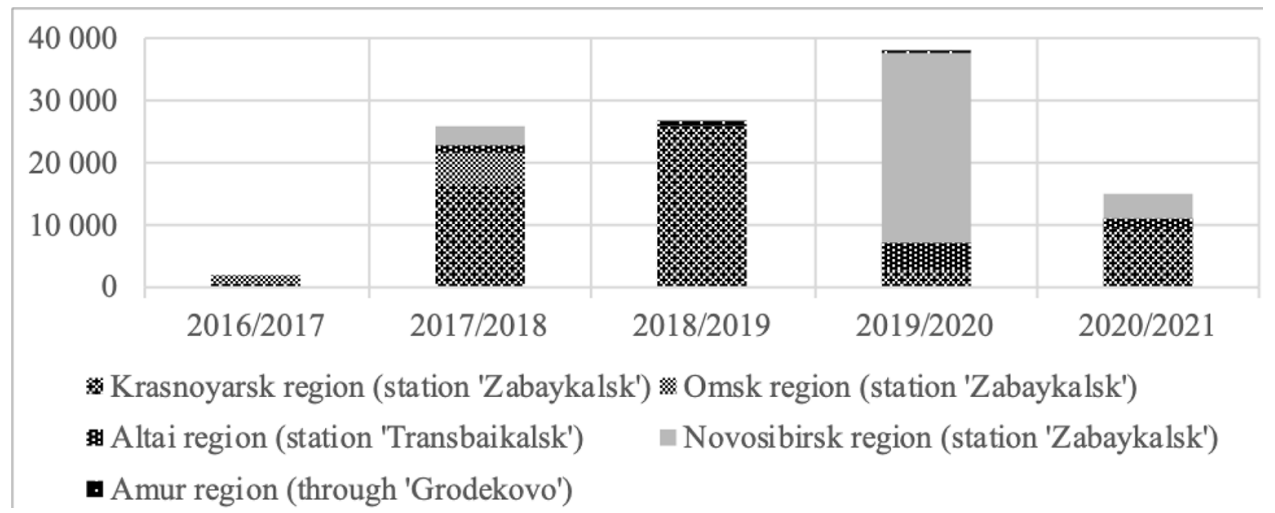

Fig. 2. Export of wheat to China by regions of the Russian Federation by rail, tons Source: Federal Customs Service of Russia

crease in grain production inevitably rests on the regional factor.

China is the main importer of Russian agricultural products: the export of Russian agro-industrial complex in which in monetary terms increased by $35 \%$ and amounted to $\$ 1.9$ billion $^{2}$. The share of China in the structure of wheat exports of all classes is less than $1 \%$ (370 thousand tons). In addition, the export prices of the Russian agricultural sector to China are also questionable and are more of a polit-

\footnotetext{
2 Analysis on agricultural access products, raw materials and food Member States of the EAEU to the market of the People's Republic of China. ECE Agro-Industrial Policy Department. Available at: http://www.eurasiancommission.org/ru/act/ prom_i_agroprom/dep_agroprom/export/Documents/Китай. pdf (Access: 10.03.2021).
}

ical factor than an economic one (Kapoguzov, Chupin, Kharlamova, 2020). At the same time, China occupies over $15 \%$ of Russian exports of flour - 73 thousand tons in 2020.

Since the «eastern» turn in 2014, the only and main exporters to China are the regions of Siberia. The dynamics of wheat exports to China is shown in Figure 2.

According to research by Russian scientists, the export potential of agro-industrial complex largely depends on the level of socioeconomic development of the regions (Krylatyh, Belova, 2018). For example, agriculture in the economy of the Siberian macro-region plays a more significant role than the Russian average. The share of agricultural production in the 
total GRP of the regions of the South of Siberia is $5.9 \%$ with an average Russian $4.8 \%$. The percentage of employed in agriculture reaches almost $10 \%$ of the total population employed in the economy (Russian average $9.2 \%$ ). In the regions, the share of agriculture in fixed assets is higher: $3.8 \%$ compared to $2.7 \%$ in the Russian Federation. However, Siberia's export capabilities are still lagging behind the performance of the European part of Russia: the share of the South of Siberia in grain exports is about $2 \%$ of the all-Russian. Looking at the average for the five-year period, Siberia produces 13-14 million tons of grain annually, of which the territory's export rarely exceeds 2.5 million tons (Danshin, 2018). At the same time, the potential of West Siberian crop production with modern efficient agricultural technologies allows us to count on 30-35 million tons of grain per year. The lack of markets and high transport and logistics costs in the western direction are traditionally considered a deterrent.

Thus, it becomes necessary to update the scientific provisions of the logistics doctrine based on the results of empirical studies of grain-producing regions, to develop mechanisms and tools for the development of the transport and logistics infrastructure of the macro-region in the conditions of export expansion of Russian grain. To begin with, export factors should be considered in a comprehensive manner. It is important to address the impact of different regional circumstances on wheat exports and the impact of these circumstances on wheat prices. The latter is crucial in determining further grain export strategies.

\section{Theoretical framework}

Many scientists are studying grain export factors (including wheat) in Russian and foreign scientific discourse. Consideration of those dealing with regional exports is of value to the study. In this context, macroeconomicbased approaches are key in addressing wheat exports (Timmer, 2000). Assessing the impact of GDP and other indicators of the system of national accounts is at the heart of them. But these studies are not characterized by a meaningful analysis of intraregional specifics, as well as factors of industry markets. For example, in studies, regional specificity is inferior to country imports, climate, oil prices when assessing the connection with changes in world wheat prices (Enghiad, Ufer, Countryman, Thilmany, 2017). It should be mentioned that such conclusions are characteristic of countries integrated into world markets (Köse, 2019), while for countries with less dependence on the dollar, the impact of macroeconomic indicators may be minimal. Based on the forecast export models of the Russian agricultural sector, the macroeconomic structure has a minor impact on the target export variable (Borisovskaya, 2018). Thus, the proposed macroeconomic approach is not considered exhaustive when considering the characteristics of regional exports.

Empirical analysis of sectoral and intraregional characteristics is an alternative to the above approach. According to new research, the thesis that food exports are from individual territories of the country has become fundamental in determining the circumstances of the trade flow (Autor, Dorn, Hanson, Li, 2018). It turns out that the parameters of regional industry markets in large territories are more important than macroeconomics. In particular, scientists from the Institute of Agrarian Problems of the Russian Academy of Sciences have proved through factor-cluster analysis that the output of products in the industry and the level of investment in agriculture in the Russian regions has a direct impact on the level of exports (Shabanov, Vasilchenko, Derunova, Potapov, 2021). However, this approach is also characterized by shortcomings. The main disadvantage of this approach is the insufficiently comprehensive coverage of the market situation, which, according to scientific research (Kulyk, 2019), is capable of ignoring the influence of cost factors and the production of agro-industrial products. The most representative case for demonstrating "market power» in export issues is the experience of the USSR in grain exports under the influence of sanctions restrictions (Lundborg, 2017). Despite the impressive indicators of grain production in the collective planned economy of the USSR and the stock armament of the industry, the export potential of the union in terms of grain exports 
was extremely low due to institutional restrictions. If we talk about Russian regions in modern conditions, then they are also in certain restrictions when revealing their export potential. Thus, the regions of Siberia with a high level of production potential of agro-industrial complex are limited in access to foreign markets (Zinina, Dalisova, Pyzhikova, Olentsova, 2019).

In general, the search for an integral approach is updated when solving the problem of increasing exports from Russian regions. The approach of M. Svanidze and L. Götz claims to be an integral approach, since the distinction between production and export potential is proposed within the framework of the proposed concept (Svanidze, Götz, 2019). It is assumed that the volume of wheat shipments from the region depends both on the level of grain production in the territory and on the combination of market factors. There is logistics arm, price level, availability of domestic shipments, trade volumes included in the latter and form the export potential of the region. But this approach does not exclude the influence of production factors, including not only wheat production and investments in fixed assets, but also the production of products of higher redistribution (including feed and flour). However, the requirements for the database and analysis methods are heightened by the need to take into account many heterogeneous and often unstructured factors.

As mentioned earlier, a factor-cluster analysis is most often used to analyse the impact of export and production capacity on wheat shipments (Zou, Guo, 2015). Recently, however, multiple regression (Gutiérrez-Moya, Adenso-Díaz, Lozano, 2021) and trend analysis (Schewe, J., Otto, C., Frieler, 2017) have been increasingly used. A key feature of these methods is the ability to identify quantitative relationships, but, at the same time, the use of these methods is extremely demanding for the structure of the data used. As a result, in practice, tools began to be used to simulate or replace missing data by dami variables (Mulla, Quadri, 2020). Based on best practices, we believe to use the machine learning approach as the most effective tool for analysing large amounts of unstructured information related to grain production and export in Russian regions.

\section{Design}

Let us summarize the preceding review by assuming key groups of factors affecting the regional export of grain. The first group of factors includes parameters of production potential, including production of wheat products (flour, feed and bread), as well as grain reserves at elevators and processors and in agricultural organizations. The second group of factors characterizes export potential. There are market volumes, domestic grain shipments and prices. At the same time, it is important to take into account these factors both in terms of regions and in time dynamics. The more observations there will be, the more suitable the model can turn out.

The study used Big Data collected and processed based on «Zol on-line» statistics (Table 1).

We have a sample of 11,484 historical observations and 15 variables. Thus, we deal with data for 74 regions from 2007 to 2021 by month. Let us look at the technical parameters of the downloaded data in table 2.

Missing values in the database were filled in zero. In addition, text variables (region, county, and month) were recoded into numeric dami variables. As a result, we obtained processed and analysed data, including the value of the target variable: the Russian region exports wheat to other countries or not. To do this, we replace the target variable with the export status, which can be set to «1» if the region exported wheat in the selected period and «0» if it did not export and domestic export. By defining the target variable, domestic exports and exports were removed from the aggregate. As a result, the resulting input variables were evaluated through a correlation matrix (Fig. 3).

Based on the available data, we are able to build regional classification models: at the input, the model will receive data on the region at a time, and at the output it should work in two modes:

- output the probability of export;

- issue a model-correct export and domestic export factors. 
Table 1. Description of measures for modelling

\section{Column Name}

\begin{tabular}{ll}
\hline Region & Name of the region of the Russian Federation \\
District & Federal District to which the region belongs \\
Domestic export & Domestic shipments of wheat by rail, tons \\
Export & Export shipments of wheat by rail, tons \\
Domestic import & Wheat received from other regions by rail, tons \\
Import & Wheat received from other countries by rail, tons \\
Month & Month for which statistics are recorded \\
Year & Year for which statistics are recorded \\
Price & Average producer prices for sold wheat, RUB ton \\
Grain reserves & Availability of grain in agricultural organizations, tons \\
Grain sales & Wheat sales by agricultural organizations, tons \\
Grain availability for processors & Availability of grain in procurement and processing organizations, tons \\
Flour production & Flour, tons production \\
Compound feed production & Production of feedstuffs, tons \\
Bread production & Bread production, tons
\end{tabular}

Source: Zol On-Line News Agency (https://www.zol.ru)

Table 2. General data statistics*

\begin{tabular}{ccccccccc} 
& count & mean & std & min & $\mathbf{2 5} \%$ & $\mathbf{5 0} \%$ & $\mathbf{7 5} \%$ & max \\
\hline Domestic export & 5387.0 & 12983.958604 & 20099.527543 & 0.0 & 1576.00 & 5884.0 & 15872.00 & 250038.0 \\
Export & 3091.0 & 31744.186024 & 56492.232610 & 1.0 & 2251.00 & 9134.0 & 35601.50 & 467572.0 \\
Domestic import & 7303.0 & 9575.648501 & 15621.990169 & 0.0 & 1059.50 & 3519.0 & 10944.00 & 228283.0 \\
Import & 924.0 & 4473.179654 & 7463.864451 & 21.0 & 630.00 & 1894.0 & 4754.50 & 74581.0 \\
Year & 11484.0 & 2013.855799 & 4.084465 & 2007.0 & 2010.00 & 2014.0 & 2018.00 & 2021.0 \\
Price & 8636.0 & 5882.048286 & 3626.589417 & 0.0 & 3939.50 & 5890.5 & 8451.00 & 22052.0 \\
$\begin{array}{c}\text { Reserves } \\
\text { Grain sales }\end{array}$ & 11411.0 & 226290.327754 & 445948.914088 & 0.0 & 4600.00 & 59000.0 & 249679.00 & 5366500.0 \\
$\begin{array}{c}\text { Grain availabili- } \\
\text { ty for processors }\end{array}$ & 11406.0 & 152655.907066 & 298562.092596 & 0.0 & 1100.00 & 30400.0 & 174525.00 & 13257120.0 \\
$\begin{array}{c}\text { Flour production } \\
\text { Compound feed }\end{array}$ & 11484.0 & 9757.131749 & 15639.273687 & 0.0 & 6.00 & 3524.5 & 14996.25 & 163394.0 \\
$\begin{array}{c}\text { production } \\
\text { Bread production }\end{array}$ & 11484.0 & 23549.999913 & 44313.168584 & 0.0 & 3.75 & 11098.5 & 27512.25 & 497167.0 \\
\hline \% & 11484.0 & 6160.969523 & 5638.832079 & 0.0 & 2404.50 & 4876.0 & 8442.50 & 37457.0
\end{tabular}

${ }^{*}$ count - the number of values that are not missing $(\mathrm{NaN})$;

mean, std, mean and variance of data in the relevant field;

the remaining statistics are minimum and maximum values, and quantifiers. 


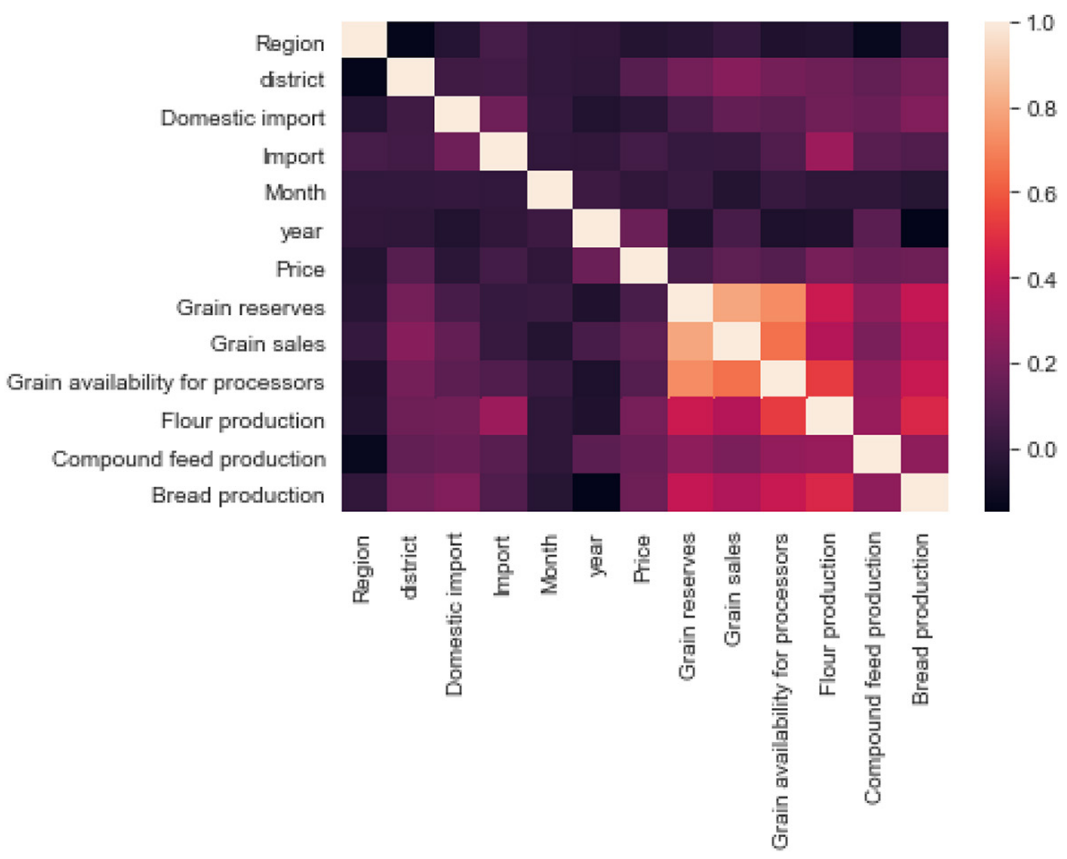

Fig. 3. Correlation matrix of model input variables

To solve the problem of classification, the sample was divided into two parts for training and for testing the model. In the training sample 9,187 observations, in the test sample 2,297 . In other words, there are many objects $X$ and many answers $Y$. Each object $x \in X$ is characterized by its own characteristic description. There is also an unknown $y$ function that is available for each $X$ element maps some element to $y$. In the task of teaching with the teacher we have a training sample $x_{1}, \ldots, x_{i} \in X$, for each object of which the correct answer $y_{i}=y\left(x_{i}\right)$ is known. Thus, build on the basis of the training sample the algorithm $a(x)$, which will approximate the function $y$ as best as possible on the whole set $X$.

Test sample used to train two models: random forest model and binary logistic regression. Logistic regression is a statistical model used to predict the probability of a certain event occurring by fitting data to the logistic curve, whereas a random forest uses a different learning algorithm. For $n=1, \ldots, N$ : Generate sub-sample $\bar{X}_{n}$ with return and build the crucial tree $b_{n}(x)$ by sample $\bar{X}_{n}$. A random tree is built until there are no more than $n_{\min }$ objects in each sheet in each node, first, $m$ random features are selected, and the optimal partition is sought only among them. Concluded in composition $a_{N}(x)=\frac{1}{N} \sum_{i=1}^{N} b_{n}(x)$. In this study, we use two methods.

\section{Results}

As part of the next analysis block, the quality of the constructed models was compared. The results of the predicted export probability measurement are shown in Figure 4.

According to the assessment of the model parameters, the random forest model, which provided the maximum recall ${ }^{3}$ and precision ${ }^{4}$, coped most effectively with the classification of export regions in the test sample. In two models, the distribution is concentrated on a segment from 0.2 to 1.0 and only a small part of

\footnotetext{
3 The completeness (Recall) of the classifier is equal to the fraction of true positive positives. This characteristic can be interpreted as the «sensitivity» of the classifier to objects of class 1 . The closer to $100 \%$, the less often the classifier «misses» a positive object (in this case, the true class 1 ).

4 The Precision of the classifier reflects how intelligently the classifier labels a positive class 1 . The higher this score, the «less common» the objects labeled 1 are actually examples from class 0 .
} 

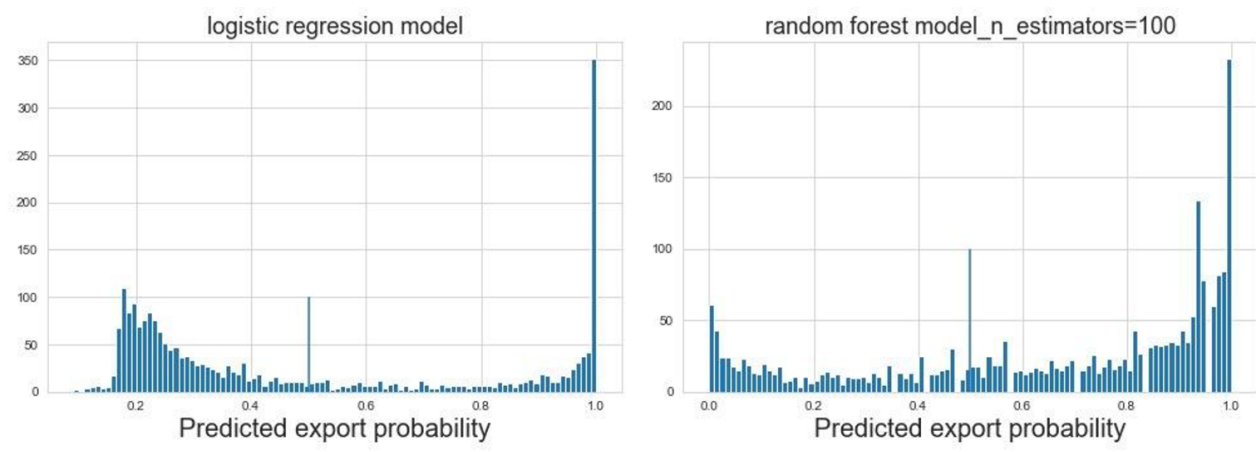

Recall: $71.47 \%$

Precision: $91.41 \%$

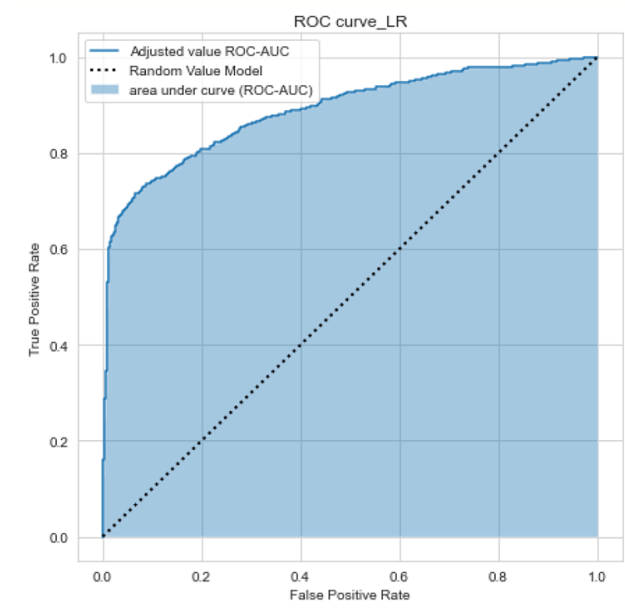

ROC-AUC on test sample: $\mathbf{0 . 8 8}$
Recall: $87.26 \%$

Precision: $91.83 \%$

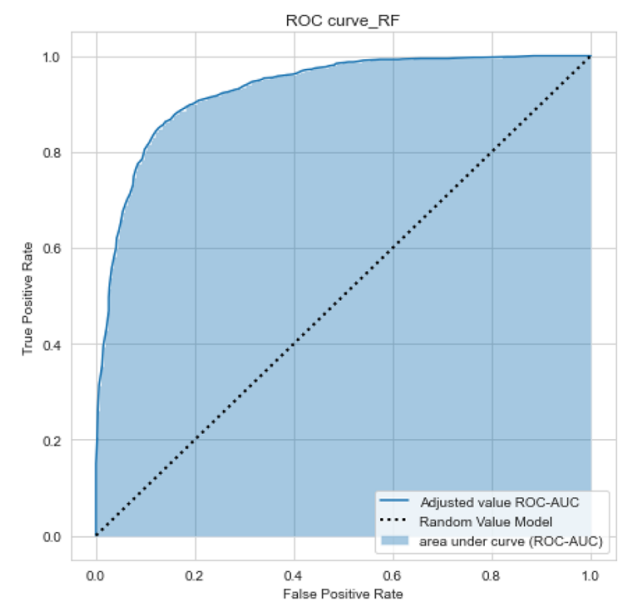

ROC-AUC on test sample: 0.96

Fig. 4. Accuracy and completeness of models

the probabilities is below the threshold of 0.2 . From this, it can be assumed that the classifier tends to classify all objects as 1 , ignoring 0 . This is because the marks 1 in the training sample are much larger than the marks 0 . In turn, the random forest model more classifies objects with a value of 0 , therefore, is more suitable for the purposes of predicting the export potential of territories. Thus, the random forest model works more often than the logistic regression model and practically rampant determines regional exports.

In addition, the random forest model shows a greater ROC-AUC on test sample, which allows us to characterize the random forest model as excellent. Obviously, not all the collected signs will be equally useful. After learning the algorithm, we can see which of the features affect the result more. To do this, we highlight the most important components in the most productive random forest model (Figure 5).

Based on the analysis, the most important export circumstance is grain sales: the parameter increases the probability of export by $49.3 \%$, which indicates the dominance of the market factor in determining the export potential of the region. In addition, export is influenced by productive capacity factors. Flour production increases the likelihood of wheat exports by $30.4 \%$. At the same time, this influence is difficult to explain, if one does not take into account the level of concentration of grain raw materials in flour mills, which often have the largest elevator capacities and carry out flour processing. It should also be borne in mind that in the model, the target variable comes only from exports to other countries, but also from domestic exports. Given that the 


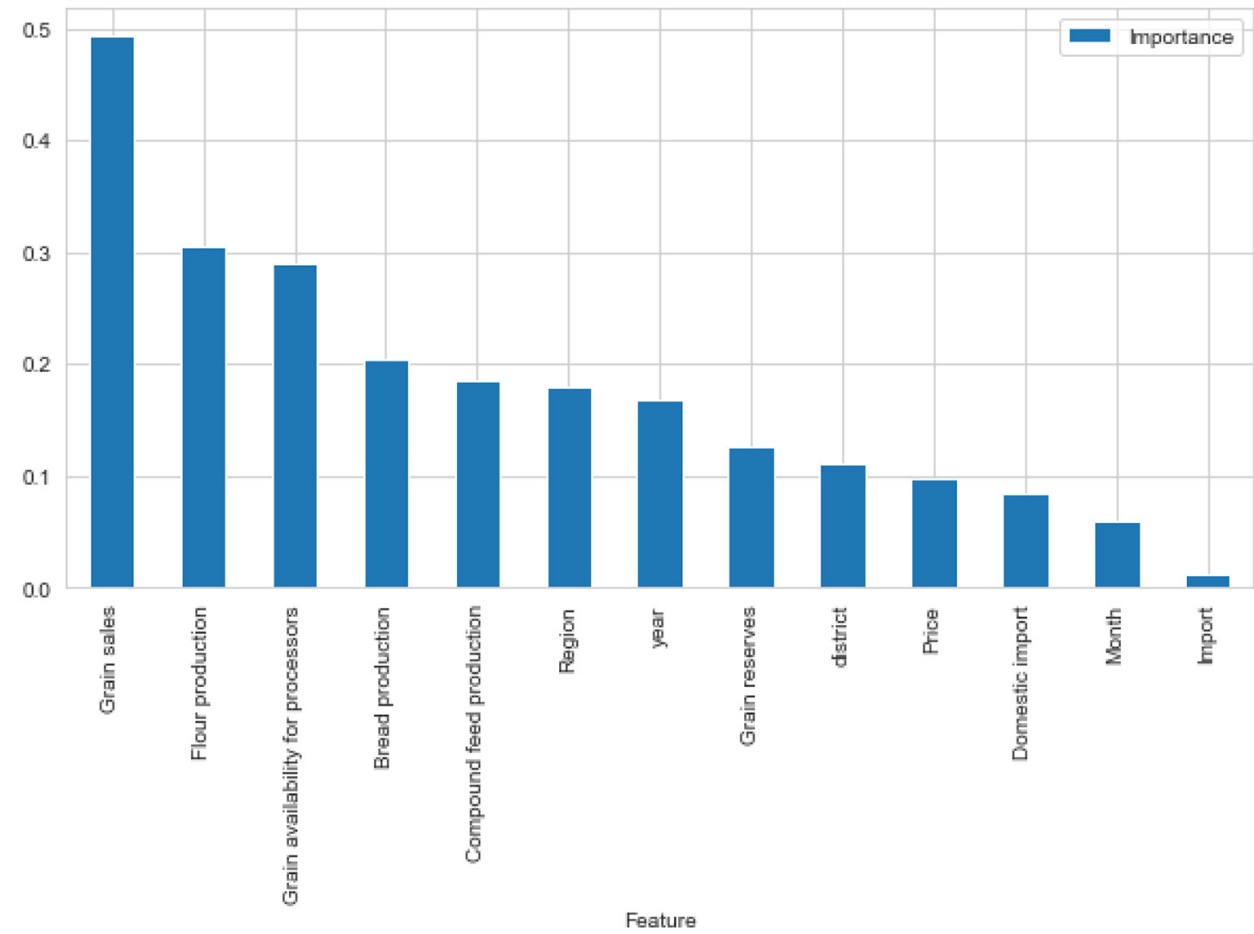

Fig. 5. Evaluation of the significance of the features by the degree of their impact on the probability of regional exports

largest Russian flour mills have elevator capacities in the regions and carry out transportation from the South of Siberia to Central Russia, the positive impact of flour production on export potential is natural. Thus, availability of grain in procurement and processing organizations increases the likelihood of wheat exports by $29.0 \%$. At the same time, bread production and the production of compound feed reduce the likelihood of export and domestic export by $20.5 \%$ and $18.6 \%$, respectively. This is also natural in the context of the use of wheat in production within the region. Thus, wheat exports from the region are more influenced by the size of the market and the level of use of cereals by the flour industry.

Once preliminary results have been obtained, the model should be supplemented with an assessment of the impact of export factors on the price of wheat. In this case, we also propose to train two models: the classical linear multiple regression model and the random forest model. Only the dependent variable will be the average prices of wheat producers in the region.

However, as a result of determining significant export factors, the sample will be significantly reduced. Taking into account the ignorance of insignificant factors, the training sample will be 4,756 observations, the test sample $-1,189$. The results of model training are shown in Figure 6.

We observe that in the case of a price forecast, the random forest model also performs much better. Therefore, we can use the random forest model to produce conclusions about significant factors (Figure 7). The most important factors are production, including the production of feedstuffs and grain reserves in producers. That is, the factors that adversely affect wheat exports from the region are the most significant in determining the price within the region.

\section{Conclusion}

As a result, factors of export potential and production potential simultaneously in- 


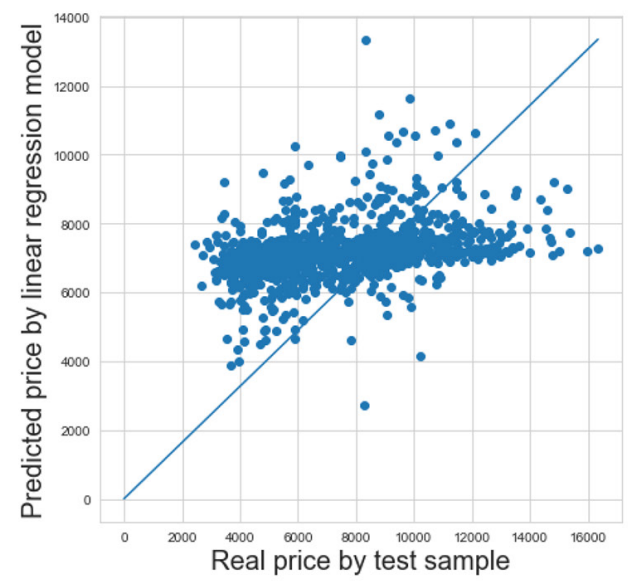

MAE: 1924.05 , RMSE: $2376.10, \mathrm{R} 2: 0.11$

for linear regression model

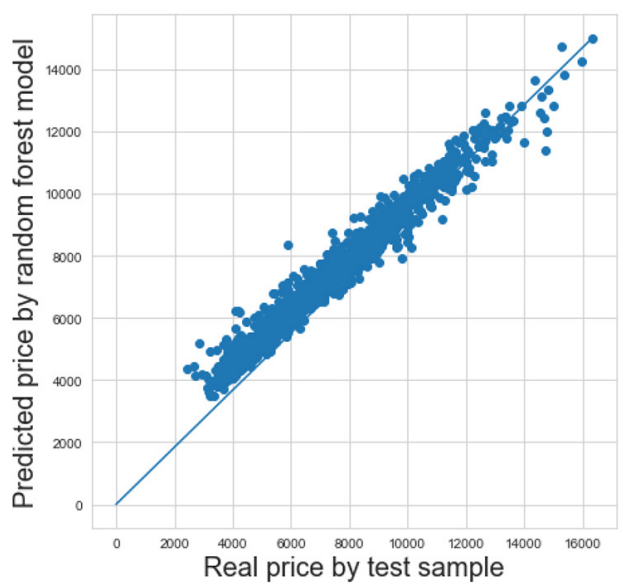

MAE: 453.27, RMSE: 613.49 , R2: 0.94

for random forest model

Fig. 6. Wheat price prediction models in regions based on significant export factors

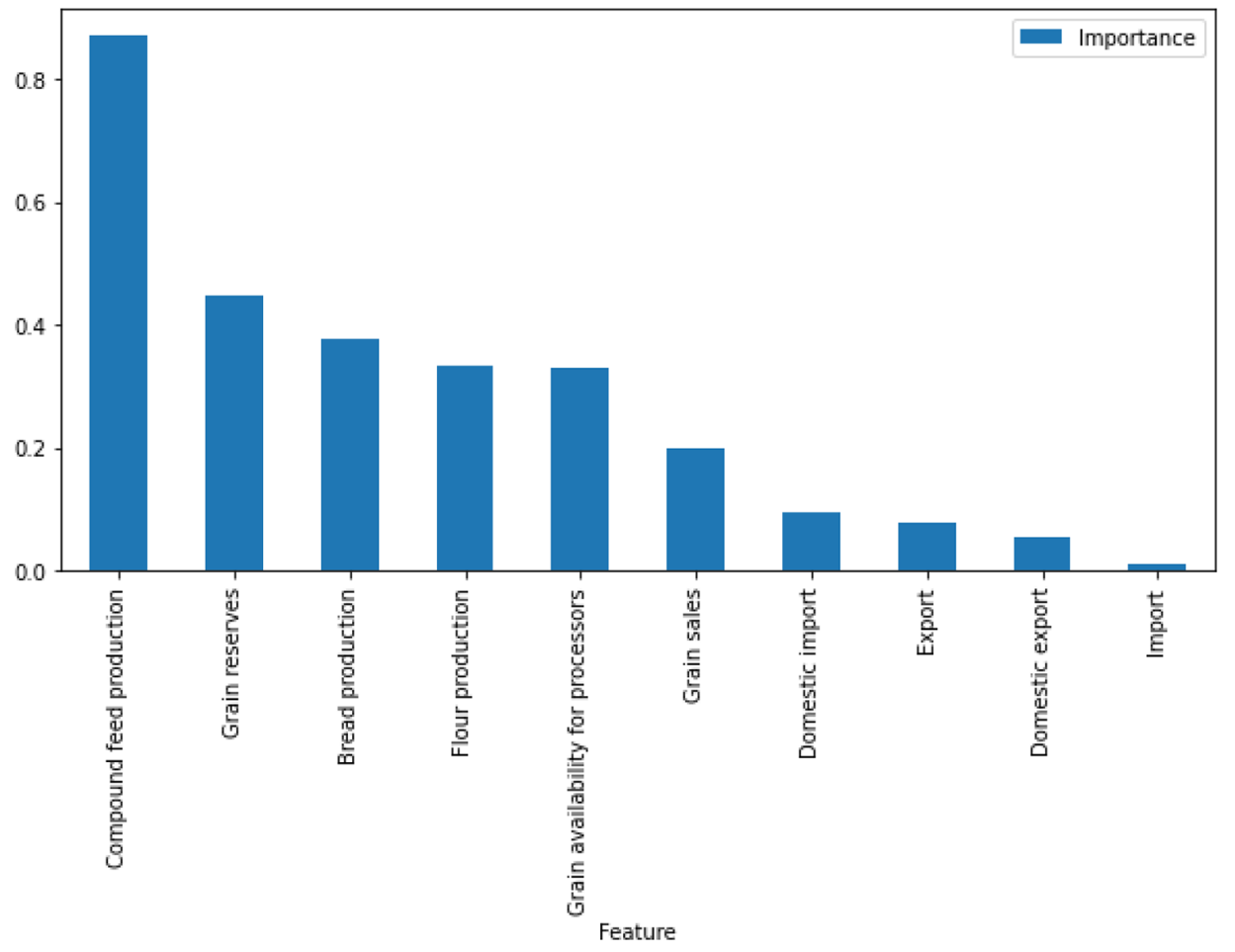

Fig. 7. Assessment of the impact of factors on wheat price

fluence wheat exports from Russian regions. This conclusion confirms the results obtained by M. Svanidze and L. Götz. Through the use of machine learning methods and Big Data, we have proved that these factors act in dif- ferent directions: market factors contribute to an increase in the likelihood of wheat exports, while processing factors (with the exception of flour production) contribute to a decrease in the likelihood of exports. This conclusion is 
very important for understanding that wheat exports from Russian regions are carried out by specific companies, while the public authorities in the development of strategic documents take this circumstance into account as an «invisible force» of exports. With the development of primary and deep grain processing within the regions, wheat exports should be reduced, while large flour producers and grain traders are not interested in this. They actively buy grain and form reserves on their own elevators, which contributes in the future to the movement of grain between regions and abroad.

Having continued the discussion on strengthening wheat exports from the regions of Siberia to China, we must take into account these circumstances. Each ton of grain to China will inevitably become a «stumbling block» between the interests of politicians, local grain processors and large federal grain companies. Without taking into account these interests, the government risk having a negative impact on the price. So, in the regions of Siberia, where the feed processing industry annually suffers a shortage of grain for production needs due to the lack of winter crop output, an increase in grain exports to China can form a negative price convention. Therefore, more dramatic changes are required to improve the logistics Doctrine.

In the Siberian grain economy, it is necessary to create a mechanism that can ensure the effective interaction of the main elements of the logistics system: "supply - production - warehousing - transportation - sales.» In this regard, the creation of an interregional network of transport and logistics centres in Siberia, which will stimulate the development of grain production and ensure the supply of grain and grain products in the necessary quantity and quality for interregional and interstate relations, becomes the cornerstone of the logistics doctrine. Methodologically, the basis for the development of the transport and logistics infrastructure of the grain market will cover the chain of grain movement from the field to the end user. Improving the efficiency of transport and logistics services of the grain market will be associated with the creation of transport and logistics centres in the region, their material and technical base, with improving the management of grain commodity flows, as well as the development and implementation of logistics schemes for goods movement.

It is assumed that transport and logistics centres will maximize the interests and capabilities of manufacturers, grain traders and owners of vehicles in the regions of Southern Siberia in the conditions of export expansion of Russian grain. As further prospects for the study, it is planned to develop scenario options for the development of grain production in the regions of the South of Siberia. In accordance with the developed scenarios, it is planned to calculate the capacities for storing grain in transport and logistics centres, the needs of the transport and logistics infrastructure of the grain market (road, railway and river transport) for each region of the South of Siberia. Based on the data obtained, a spatial layout of transport and logistics centres for the regions of the South of Siberia will be modelled.

The results of the study will be used in the development of the Interregional program «Development of the grain market of Siberia for the period until 2025,» including to achieve the targets of the Federal project «Export of agricultural products».

\section{References}

Autor, D.H., Dorn, D., Hanson, G.H., Li, L. (2018). Understanding Regional Export Growth in China, In World Trade Evolution: Growth, Productivity and Employment, 195.

Borisovskaya, K.A. (2018). Economic and Mathematical Modelling of Food Exports' Turnover in Russia on a Mid-Term Horizon, In European Research Studies, 21, 582-589.

Danshin, A.I. (2018). Eksportnyi potentsial agropromyshlennogo kompleksa Sibiri i Dal'nego Vostoka [Export potential of the agroindustrial complex of Siberia and the far East], In Vestnik Moskovskogo universiteta. Seriia 5, Geografiia [Bulletin of Moscow University. Series 5, Geography], 4, 101-108. 
Gutiérrez-Moya, E., Adenso-Díaz, B., Lozano, S. (2021). Analysis and vulnerability of the international wheat trade network, In Food security, 13(1), 113-128.

Kapoguzov, E.A., Chupin, R.I., Kharlamova, M.S. (2020). Importozameshchenie v miasnoi promyshlennosti: ekspansiia za dollar [Import Substitution in the Meat Industry: Expansion for One Dollar], In EKO [ECO], 11, 104-123.

Krylatyh, E.N., Belova, T.N. (2018). Eksport rossiiskogo zerna v kontekste formirovaniia regional'noi ekonomicheskoi politiki [Russian grain exports in the context of regional economic policy], In Ekonomika regiona [Economy of Region], 14(3), 778-790.

Kulyk, I. (2019). Analysis of impediments to grain export from Russia, Ukraine and Kazakhstan: Three essays (No. 93). Studies on the Agricultural and Food Sector in Transition Economies.

Lundborg, P. (2017). The Economics of Export Embargoes: The Case of the US-Soviet Grain Suspension (Vol. 9). Routledge.

Mulla, S.A., Quadri, S.A. (2020). Crop-yield and Price Forecasting using Machine Learning, In International journal of analytical and experimental modal analysis, 12(8), 1731-1737.

Rau, V.V. (2017). Russian food exports: Trends, opportunities, and priorities, In Studies on Russian Economic Development, 28(4), 431-436.

Shabanov, V.L., Vasilchenko, M.Y., Derunova, E.A., Potapov, A.P. (2021). Formation of an ExportOriented Agricultural Economy and Regional Open Innovations, In Journal of Open Innovation: Technology, Market, and Complexity, 7(1), 32.

Schewe, J., Otto, C., Frieler, K. (2017). The role of storage dynamics in annual wheat prices, In Environmental Research Letters, 12(5), 054005.

Svanidze, M., Götz, L. (2019). Spatial market efficiency of grain markets in Russia: Implications of high trade costs for export potential. Global Food Security, 21, 60-68.

Timmer, C.P. (2000). The macro dimensions of food security: economic growth, equitable distribution, and food price stability, In Food policy, 25(3), 283-295.

Enghiad, A., Ufer, D., Countryman, A.M., Thilmany, D.D. (2017). An overview of global wheat market fundamentals in an era of climate concerns, In International Journal of Agronomy, 2017, 1-15.

Zinina, O.V., Dalisova, N.A., Pyzhikova, N.I., Olentsova, J.A. (2019). Development prospects of the Krasnoyarsk region agroindustrial complex in the export conditions, In IOP Conference Series: Earth and Environmental Science, 315(2), 22-68.

Zou, J., Guo, S. (2015). China's food security evaluation based on factor analysis, In American Journal of Industrial and Business Management, 5, 447-456.

Köse, M.B. (2019). Empirical analysis and multiple regression modelling of influential factors behind wheat prices in future market. Doctoral dissertation, University of Geneva. Available at: https://archiveouverte.unige.ch/unige:124752 (Access: 23.04.2021). 